\title{
The effect of solid waste management investments in the Republic of Serbia'
}

\section{Ефекат инвестирања у управљање чврстим отпадом у Републици Србији}

\author{
Aleksandra Pavlović * \\ University of Novi Sad, Faculty of Technical Sciences, Novi Sad, Republic of Serbia, pavlovic.di8.2018@uns.ac.rs \\ Andrea Ivanišević \\ University of Novi Sad, Faculty of Technical Sciences, Novi Sad, Republic of Serbia, andreai@uns.ac.rs \\ Ivana Katić \\ University of Novi Sad, Faculty of Technical Sciences, Novi Sad, Republic of Serbia, ivana.katic@uns.ac.rs \\ Alpar Lošonc \\ University of Novi Sad, Faculty of Technical Sciences, Novi Sad, Republic of Serbia, alpar@uns.ac.rs \\ Mladen Radišić \\ University of Novi Sad, Faculty of Technical Sciences, Novi Sad, Republic of Serbia, radisicm@uns.ac.rs
}

\begin{abstract}
The problem of establishing an effective solid waste management system is complex and still unresolved in Serbian municipalities, cities and settlements. Most landfills in Serbia do not meet basic sanitary standards and can often contain waste that is dangerous to human, plant and animal health, and waste that can be recycled is often dumped. The aim of this paper is to investigate the relationship between waste generation and private investments in waste management. Statistical method of multiple linear regression was used to examine the impact of three predictors - economic development, investments in waste management, and urban population, on the dependent variable - municipal solid waste generation. The results of the research reveal that investments in waste management in Serbia do not have an effect on the waste reduction because the financial resources for such investments are not adequately managed. There is a large number of scientific researches that have dealt with the analysis of the mentioned relationship, however, their number on the example of Serbia is rather scarce. The results of the research could be useful to the state administrations of the Republic of Serbia.
\end{abstract}

Keywords: investments, municipal waste, waste generation, regression analysis JEL classification: E22, Q57

Сажетак: Проблем успостављања ефективног система управљања чврстим отпадом комплексан је и још увек нерешен у српским општинама, градовима и насељеним местима. Већина депонија у Србији не задовољава основне санитарне стандарде и на њима се често може наћи отпад опасан по живот и здравље људи, биљака и животиња, а често се баца и отпад који је могуће рециклирати. Циљ овог рада је сагледавање односа између генерисања отпада и приватних инвестиција у управљање истим. У раду је примењен статистички метод вишеструке линеарне регресије, како би се испитао утицај три предиктора привредни развој, инвестиције у управљање отпадом, и урбана популација, на зависну варијаблу генерисање чврстог комуналног отпада. Резултати истраживања показали су да у Србији инвестиције у управљање отпадом немају ефекат на редукцију истог јер се финансијским средствима за таква улагања не управља адекватно. Велики је број научних истраживања која су се бавила анализом поменутог

${ }^{1}$ The paper is the part of the project "Foreign language teaching, social and economic relations in the light of changes in 2021 "which is funded by the Faculty of Technical Sciences in Novi Sad.

Corresponding author 
односа, међутим, њихов број на примеру Србије је прилично оскудан. Резултати истраживања могли би бити од користи државним управама Републике Србије.

Кључне речи: инвестиције, комунални отпад, генерисање отпада, регресиона анализа JEЛ класификација: E22, Q57

\section{Introduction}

The question of impact of investments, both domestic and foreign, on the economic growth of the country has been a burning question for many years which numerous eminent researchers have tried to answer. Thus, Serbia has gradually become an attractive destination for foreign investors, thanks to its many advantages, and nowadays, it is possible to notice the growth trend of foreign investments in Serbian municipalities and cities (Stojanović et al., 2017). Attracting brownfield investments, where technical and traffic infrastructure already exists, is especially important for the economic growth of Serbia (Sredojević et al., 2019). Nowadays, developing economies are becoming essential participants in the movement of foreign direct investment, primarily as a popular destination (Obradović \& Lojanica, 2015). On the other hand, the question of impact of economic activities on the environment has long been overshadowed, but there has been encouraging interest in that question as well. Paul Van Der Merwe: "Money makes the world go round" is not far from the truth. Individuals, groups of individuals, and companies in national and international businesses are striving to make as much profit as possible, giving preference to the material over the natural. Just as wealth is not worth much to a sick man in an expensive suit, as he cannot buy health with it, so the wealth will not be of great benefit to the rich world economies if they do not have a healthy environment. The authorities of developed and developing countries must accept the fact that money cannot buy everything and that there has to be a way to increase economic growth without endangering the environment. Kenneth Boulding, a British economist (Boulding, 1966), in his essay vividly describes that planet Earth is not the Wild West where people, like cowboys, take everything in their path, expecting resources to always be in abundance, but a unique, closed system, resembling a spaceship, where humans must rationally use the limited resources given to them, in order to survive. Environmental economists agreed with the fact that the "space" economy should be led against the "cowboy" economy. Proponents of the conventional economics see the economy as a closed system that is self-sufficient and in which prices of products, services and factors of production are formed, while supporters of the ecological economics see the economy as an open system embedded in the ecosystem (Martinez-Alier, 2001). Proponents of this theory believe that the ecological economics is not a pure economics or ecology, but their mix, which recognizes the fact that the human economy is part of the natural world and the environment is a source of resources that are limited and scarce, as well as a place of waste storage.

Ecological economics is a transdisciplinary effort to broadly link the natural and social sciences, especially economics and ecology (Costanza, 2008). It recognizes the importance of efficient resource allocation, but requires a much deeper understanding of the relationship between economic development and resource exploitation (Neo, 2009). In 
today's economy, natural resources are extracted from ores and transformed into products that are discarded after use, and such products become waste. However, a large part of that waste can be recycled, i.e. reused, and that, unfortunately, is not always the case in practice. This issue is dealt with by the circular economy. Circular economy is an approach that transforms the function of resources in the economy - factory waste becomes a valuable raw material in another production process, and the products themselves can be repaired, reused or improved, instead of being discarded (Đureta et al., 2016). It is an alternative to the outdated model of linear economy, which starts from the principles "take - make - use - throw". The third most important anthropogenic source of methane emissions is waste management system (Živančev et al., 2020), i.e. this sector produces emissions of carbondioxide, black carbon and methane, which are one of the biggest environmental degraders nowadays. Although the term municipal solid waste (MSW) is not precisely defined in professional literature, it can be said that MSW is solid waste from households and commercial sector (Stepanov, 2018). Waste is not managed by creating landfills by the roadsides or in remote places. Proper waste management requires waste management plants and storages. Waste management plant is a stationary technical unit for storage, treatment or disposal of waste, which together with the construction part forms a technological unit, while the waste storage is the temporary storage of waste at the location of the producer or owner of waste, as well as the activity of the operator in a plant equipped and registered for temporary storage of waste (Nešić, 2010).

The term investment comes from the Latin word investitio, which means investing capital in some, usually, lucrative business (Petrović \& Denčić-Mihajlov, 2011). In theory, there are a number of different definitions of the term investment and investing. Although there is no general agreement on the definition of investment, it can be said that mostly all well-known authors agree with the basic premise that investment, i.e. investing is giving up spending financial assets in the present in order to get certain benefits in the future. Private investments are crucial in the field of waste management because they have clear ownership, responsibility, and the rules are simpler than public investments. Thus, the money investments for environmental protection purposed for waste management are necessary to provide the optimal development, i.e. there is an optimal strategy for a country to be chosen in any economic development state (Grabowski \& Vasconcelos, 1993). The funds allocated for waste management investments are usually large. Thus, the valuation of such, as well as any other investment venture, starts from the estimated future cash flows generated by the engagement of the investment (Valović Begović et al., 2017).

The goal of this paper is to study the impact of economic growth, investments in waste management and urban population on municipal solid waste generation of the Republic of Serbia, considering that in this country as well as in the countries of the region, this issue has been quite neglected.

This paper is structured as follows: unit 1 gives a theoretical background of previous research on the relationship between waste generation, economic growth and investments in waste management, and waste management in general. Unit 2 provides a short overview of the current state of waste management and investments in environmental protection in 
Serbia. Unit 3 deals with data sources, methodology and research results. In the last part of the manuscript, a conclusion is given.

\section{Theoretical background}

A number of foreign authors have addressed the relationship between environmental investments, economic growth and MSWG. However, to the best of the authors' knowledge, there are no scientific papers that have dealt specifically with this issue on the example of Serbia.

Investment flows themselves are a factor of growth and development of the economy, regardless of their internal or external origin (Kalaš, 2015). Thus, natural capital's investment and maintenance should be considered to avoid economic depression and breakdown arising from depletion of natural capital, considering that the consumption of natural capital in economic activities is faster than its recovery, in ecological system (Zhonghua \& Yu, 2011). Municipal waste management investments contribute mainly to the effects in the field of environmental governance, economic and social aspect of sustainable development (Mesjasz-Lech, 2014). Any pollution of nature will have an effect on the sustainable development of the country, i.e. as sustainability accomplishments of current manufacturing technology could be imperilled by individualisation trend as variability in environmental impacts increases (Briem et al., 2019). Investments needed to improve municipal waste collection and transportation services can be financed partially or entirely from the private sector (European Bank for Reconstruction and Development, 2018). Manufacturing sector is one of the largest waste generators. In addition to environmental issues, such as waste, economic issues must be taken into account in this sector, such as quick ratio and sales growth which have significant positive impact on profitability of manufacturing companies (Dakić \& Mijić, 2020).

A group of authors (Nunes et al., 2007) conducted a study of the impact of investments on the construction and demolition waste generation, in the recycling centres of Brazilian municipalities. The results revealed that under current market conditions, construction and demolition waste recycling centres are not financially attainable, based entirely on sales revenue. Meanwhile, under the same market conditions, the recycling centres could be economically attainable in public sector. Another group of authors (Huang et al., 2014) examined the relationship between investments and waste generation, especially food waste, on the example of 100 communities in Shanghai, China. The authors concluded that, despite the state providing large financial support for investments in waste management - about 1.37 million Yuan per district, that is not enough. Public investments are not enough on their own, they cannot be efficient enough because of a traditional lack of rigorous use of data, clarification of roles, and supporting enforcement legislation, thus, private investments in waste management are necessary. Researchers (Cui et al., 2020) have addressed the issue of public-private partnerships in the waste-to-energy incineration industry in China. The results showed that public-private partnerships in the waste-toenergy incineration in China are currently in a phase of rapid expansion. However, the quality and quantity of municipal waste, sustainable development question and the 
emerging public opposition are the main challenges in sustainable and healthy development of public-private partnerships in the waste-to-energy incineration industry in China. Investment in municipal waste management has begun to grow in India (Appasamy \& Nelliyat, 2007), however, municipal officials and the public are not aware of the magnitude of the costs involved or how to finance those expenditures and investments. Therefore, each urban local authority must develop a financial plan based on its own needs and requirements, in order to improve the quality of the urban environment for its citizens.

Agyapong (Agyapong, 2017), in his work, dealt with the issue of e-waste management. He used a review of documentation to assess the approach to financing ewaste proposed by the Ghanaian government. As a product of this study, an alternative financing model has been proposed - encouraging the participation of both private and public, as well as domestic and foreign investments. It is expected that such investments will promote the purchase of the necessary e-waste management technology. Another study highlighted the importance of public-private partnerships in financing waste management (Badu et al., 2015). Research has indicated a growing transition from the government supply of sanitary resources to a demand-side approach of private provision, and potential tools have also been proposed to improve the financing and delivery of sanitary infrastructure. Also, a group of authors from Portugal (Maia et al., 2013), among other things, proposed in their work recycling materials in the textile and clothing industry as an alternative to satisfy consumer demand. Thus, another group of authors (Hora et al., 2016) explores recycling as a waste treatment and suggests product modularity as a solution. Product modularity can facilitate product upgrades and recyclability, and thus, promote the adoption of sustainability clusters such as circular economy and longevity.

\section{An overview of the current state of waste management and investments in environmental protection in Serbia}

When it comes to the state of the environment, in most international rankings, Serbia is poorly ranked. For example, American University of Yale, every other year publishes an index on the state of the environment, known as Environmental Performance Index - EPI. According to the latest data from 2020 (Environmental Performance Index, 2020), Serbia is in the group of the worst ranked European countries, according to this index, on the position 33 out of 43 European countries, and with a total score of 55.20 out of 100 (Figure $1)$. 
Figure 1: European countries ranking according to the Environmental Performance Index (2020)

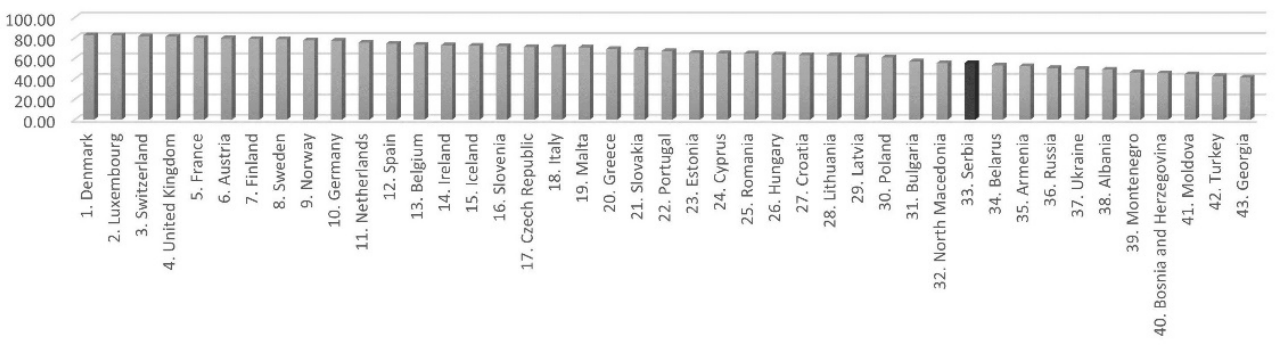

Source: the authors' creation based on EPI Yale data

Insufficient funds for environmental protection are allocated from the budget and company funds in Serbia, and precise, comprehensive and fully comparable data on the volume of these allocations are not available, while, on the other hand, the widest range of international and domestic statistics reveals that environmental investments in Serbia are two to three times less than in the countries of Central and Eastern Europe (Fiscal Council of the Republic of Serbia, 2018). Environmental investments include investments related to environmental activities (methods, technologies, processes, equipment and their parts, etc.) in order to collect, treat, monitor and control, reduce, prevent or eliminate pollution or any other environmental degradation resulting from business (Serbian Environmental Protection Agency, 2018). Of the total amount of funds for investments and current expenditures for environmental protection, the greatest need is for investments in waste management and nature protection, so Serbia, which is currently in the process of joining the European Union, will have to allocate significantly more funds for environmental investments, in accordance with the recommendations and requirements of the European Union on that issue (Fiscal Council of the Republic of Serbia, 2018; Serbian Environmental Protection Agency, 2018). It is estimated that public investment in environmental protection would have to increase by around $€ 500$ million (1.3\% of GDP) (Fiscal Council of the Republic of Serbia, 2018). Investments for environmental protection purposed for waste management are still insufficient. Considering the publicly available data from the Statistical Office of the Republic of Serbia, the lowest value of these investments was recorded in 2009 (934,139 RSD), from 2011 to 2013 investment growth was maintained, with the highest value in 2013 (4,533,799 RSD), afterwards, 2014 and 2015 were years of significant decline (Figure 2). 
Figure2: Total investments for environmental protection purposed for waste management, in thousand RSD

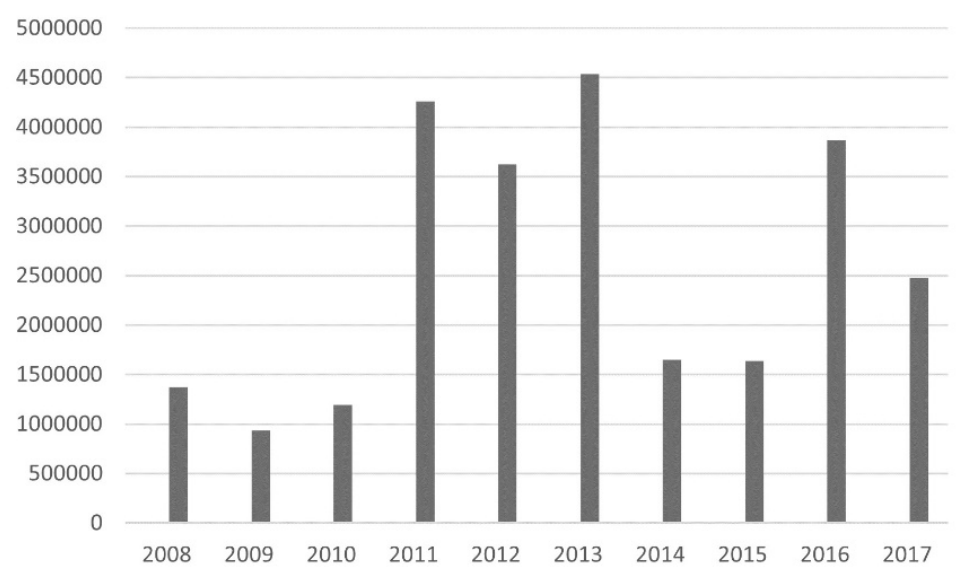

Source: the authors' creation based on Statistical Office of the Republic of Serbia data

In Serbia, on the territory of 114 local self-government units, public utility companies dispose of waste in an organized manner at 137 unsanitary landfills located in 111 municipalities, while 61 landfills do not keep any records of waste receipt and illegal dumpsites, which are beyond the control of municipal public utility companies, about $20 \%$ of MSW generation is thrown away (Serbian Environmental Protection Agency, 2020). Illegal landfills are a big problem for all municipalities because they occur almost every day, most often in rural areas, along roads, rivers or in inaccessible areas, and their exact number is not known. It can be said that they are a consequence of inadequate legislation and penal policy in the field of environmental protection. The previous waste management strategy (2010-2019) did not give the expected results; there is still a lot of waste and it is not managed adequately. Significantly fewer sanitary landfills were built than planned. New waste management strategy (2019-2024) represents the transition from the model of regional sanitary landfills to the model of regional waste management centres (separate collection, sorting, recycling and treatment of waste). The implementation of this strategy and the new legal framework on waste management is expected to create new jobs and employ more workers, which will contribute to poverty reduction, development of the "green economy" and integration of the Roma population engaged in the collection of recyclables into society (Nešić, 2010). Of the waste that is dangerous to the life and health of humans, animals and plants, significant amounts are electrical and electronic equipment, lead batteries, waste oils and waste containing oils (Serbian Environmental Protection Agency, 2020). In the total waste of the Republic of Serbia, hazardous waste participates with as much as $31 \%$, which is quite an unenviable level (Figure 3 ). 
Figure3: Participation of hazardous and non-hazardous waste generation in the total waste generation of Serbia

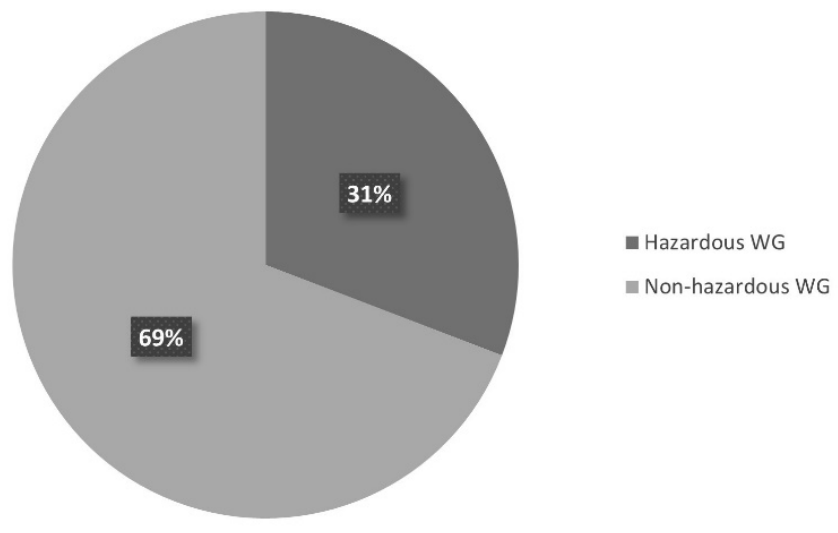

Source: the authors' creation based on Statistical Office of the Republic of Serbia data

It can be concluded that Serbia has a problem of inadequate disposal of financial resources and insufficient allocation of funds for public environmental investments as well as insufficient private investors who are essential in the field of waste management.

\section{Methodology, data and results}

Serbia's biggest challenges in the process of European integration in the field of environmental protection include large investments in waste management infrastructure and wastewater treatment (from 5.5 to $€ 7$ billion in the next 25 years) (Flanders Investment and Trade, 2017). Most landfills in Serbia do not meet basic sanitary standards. Serbian landfills, both "wild" and municipal, are big polluters, the so-called "environmental time bombs", because they can contain a variety of waste, both hazardous and non-hazardous. Thus, the surface layers of the soil are loaded with large amounts of waste materials that cannot be decomposed by self-purification processes, which leads to soil degradation (Ugrinov \& Stojanov, 2010). With precipitation (rain, snow, etc.), water will be filtered through waste, reaching plants and animals that will be found in the human food chain, which will have negative consequences for the ecosystem and human life and health. MSW management projects recorded in the PPI database ${ }^{2}$ are infrastructure projects related to public services of collection, transfer, treatment and disposal of MSW, with a minimum private sector participation of $20 \%$ and an investment size of $\$ 1$ million (World Bank, 2018). The public sector is not able to reduce the pile of MSW independently, and the goal is to gradually replace the public sector with the private sector in this segment of communal

\footnotetext{
${ }^{2}$ Private Participation in Infrastructure (PPI) database.
} 
services. Given the above, it is justified to say that private investments are crucial in the waste management field.

This paper analyses the relationship between investments in waste management and municipal solid waste generation (MSWG) in Serbia in the period from 2008 to 2018. The time frame is determined based on the availability of data. All necessary data were taken from the official website of the Statistical Office of the Republic of Serbia and the World Bank. In order to analyse the mentioned relationship, a multivariate linear regression model was applied (equation (1)):

$\ln \left(\mathrm{MSWG}_{i t}\right)=\beta_{0_{i}}+\beta_{1_{i}} \ln \left(\mathrm{GDP}_{i t}\right)+\beta_{2_{i}} \ln \left(\mathrm{InvWM}_{i t}\right)+\beta_{3_{i}}\left(\mathrm{UPOP}_{i t}\right)+\varepsilon_{i t}$

where: $i(i=1,2, \ldots m)$ is location index (country, region, etc.); $t(t=1,2, \ldots n)$ is time index; MSWG is a dependent variable, expressed in thousands of tons; GDP is Gross Domestic Product used as a proxy of economic development of the country, expressed in a constant unit of domestic currency (RSD); InvWM are investments in waste management, expressed in thousands of RSD; UPOP is urban population of the Republic of Serbia, expressed as a percentage of the total population; $\beta_{0}$ is a constant; $\beta_{1}$ is the regression coefficient that stands next to the predictor GDP; $\beta_{2}$ is the regression coefficient that stands next to the predictor InvWM; $\beta_{3}$ is the regression coefficient that stands next to the predictor UPOP; $\varepsilon$ is the measurement error. In addition to InvWM as a dependent variable, both GDP and UPOP were taken as independent variables, too, given the significant impact they have on MSWG. All data were transformed into natural logarithms to reduce the impact of data fluctuation and heteroskedasticity (Shen et al., 2020). IBM SPSS Statistics 25 software package was used for statistical data processing.

Table 1 represents the descriptive statistics of variables for Serbia, while Table 2 represents the descriptive statistics of the regression output.

Table 1: Descriptive statistics

\begin{tabular}{|l|c|c|c|c|}
\hline \multicolumn{1}{|c|}{ Descriptive stat. } & MSWG & GDP & InvWM & UPOP \\
\hline Mean & 17.59 & 29.09 & 14.61 & 4.01 \\
\hline Std. & 0.31 & 0.05 & 0.58 & 0.01 \\
\hline Min & 16.92 & 29.04 & 13.75 & 4.00 \\
\hline Max & 17.88 & 29.19 & 15.33 & 4.03 \\
\hline N & 11 & 11 & 10 & 11 \\
\hline Valid N & \multicolumn{4}{|c|}{10} \\
\hline
\end{tabular}

Source: SPSS analysis output, the authors' interpretation

Table 2: Descriptive statistics of regression output

\begin{tabular}{|l|c|}
\hline $\mathrm{R}$ & 0.99 \\
\hline $\mathrm{R}^{2}$ & 0.97 \\
\hline Adjusted $\mathrm{R}^{2}$ & 0.96 \\
\hline Std. error & 0.06 \\
\hline $\mathrm{N}$ & 10 \\
\hline
\end{tabular}

Source: SPSS analysis output, the authors' interpretation 
Given the coefficient of determination $\left(\mathrm{R}^{2}\right)$ which is a measure of "explained variation", it can be concluded that $97 \%$ of the total variation of MSWG is explained by regression. The standard error as a measure of "unexplained variation" is 0.06 .

In order to examine the validity of the entire regression model (1), the F-statistics was applied (Table 3), while in order to examine the individual utility of independent variables in predicting the dependent variable, the t-test was applied (Table 4).

Table 3: F-test

\begin{tabular}{|c|c|c|}
\hline Model & F & Significance \\
\hline Regression & 72.99 & 0.000 \\
\hline
\end{tabular}

Source: SPSS analysis output, the authors' interpretation

The regression model is statistically significant at the significance level $\alpha=0.05$ due to a very small $\mathrm{p}$-value $\left(0.000^{3}<0.05\right)$, and the null hypothesis is rejected because there is a regression dependence between the observed variables.

Table 4: Regression coefficients and t-test

\begin{tabular}{|l|c|c|c|}
\hline \multicolumn{1}{|c|}{ Model } & B & $\mathrm{t}$ & Significance \\
\hline Constant & 11.52 & 0.53 & 0.61 \\
\hline GDP & -5.72 & -5.29 & 0.002 \\
\hline InvWM & 0.24 & 5.67 & 0.001 \\
\hline UPOP & 42.10 & 9.39 & 0.000 \\
\hline
\end{tabular}

Source: SPSS analysis output, the authors' interpretation

It can be concluded that for all predictors it is possible to reject the null hypothesis because their $p$-values are less than the significance level 0.05 . These variables are individually useful in predicting the dependent variable MSWG. The model predicts that an increase in GDP by 1\% will lead to a decrease in MSWG by 5.72 in tons; then, it is also predicted that an increase in InvWM by $1 \%$ will lead to an increase in MSWG by 0.24 in tons, increases the MSWG by 42.10 in tons, assuming that the other variables in the model are fixed.

After the obtained results, the regression equation (1) can be expressed in the following form:

$\ln \mathrm{MSWG}=11.52-5.72 \ln \mathrm{GDP}+0.24 \ln \mathrm{InvWM}+42.10 \ln \mathrm{UPOP}+\varepsilon$

It turned out that GDP has a negative impact on waste generation, which is good because it says that there are enough financial resources available to invest in waste management infrastructure and to reduce the waste. From 2014 to 2018, Serbia recorded a constant significant increase of GDP per capita and has sufficient funds for the MSW reduction, however, these funds are not adequately managed, given that investments in waste management have no effect in waste reduction. The problem may be insufficient allocation of funds for public environmental protection investments, as well as insufficient

\footnotetext{
${ }^{3}$ The value is not zero but higher than it, but it is so small that the SPSS program displays it as 0.000 .
} 
private investors. Urbanization has also increased the amount of waste in Serbia, so it is inconceivable that such a country, with a relatively small population, disposes of over 2 million tons of waste annually, while at the same time waste management is not at an enviable level.

\section{Conclusion}

Serbia has a problem establishing an effective waste management system. Most landfills in Serbia do not meet basic sanitary standards and can often contain waste that is dangerous to human, animal and plant life and health, and recyclable waste is often dumped. Despite the adoption of the new Waste Management Strategy, Serbia continues to struggle with environmental problems, and a lack of social awareness and insufficient investments in environmental protection are possible causes of these problems.

There is an increasing number of "wild" landfills for which it is not possible to determine the exact number because they occur almost every day, and the outbreak of fires and even explosions is not a rare occurrence at such landfills. The reason for frequent unsanitary landfill fires is that methane, a poisonous gas that is easily flammable, is released, and one of the major consequences is air pollution. Data on the exact costs and sources of waste management financing in Serbia are given only on paper, i.e. new Waste Management Strategy, while the funding implemented in practice does not match what was planned in the strategy. The government collects a large part of the funds from environmental taxes and fees; however, these funds are not returned into the environmental protection system and waste management system, both at the local and national level.

The conclusion is that Serbia must work on raising the awareness of the citizens themselves about the importance of preserving the environment and proper waste disposal, but there must also be the government support to invest "green" money in solving problems in the field of environmental protection, as well as introducing stricter legislation and penal policy in this area. Furthermore, the recommendation to future researchers in the field of environmental economics is to put more emphasis on this so important but neglected linkage between investments and waste management, and to produce more scientific research on this issue in Serbia.

\section{References}

Agyapong, D. (2017). Alternatives for financing waste management: Implications for Ghana's growing electronic and electrical equipment waste. Asian Journal of Economics, Business and Accounting, 2(1), 1-14. Doi: https://doi.org/10.9734/AJEBA/2017/31409

Appasamy, P. P., \& Nelliyat, P. (2007). Financing Solid Waste Management: Issues and Options. Paper presented at the International Conference on Sustainable Solid Waste Management, India, url:

$\underline{\text { https://citeseerx.ist.psu.edu/viewdoc/download?doi=10.1.1.507.8771\&rep=rep1\&type }=\text { pdf }}$ 
Badu, E., Owusu-Manu, D., Donkor-Hyiaman, Conway, C., \& Edwards, D. J. (2015). Innovative financing mechanisms for delivering sanitation infrastructure. Mindanao Journal of Science and Technology, 13, 238-258.

Boulding, K. E. (1966). The economics of the coming Spaceship Earth. In Jarrett H. (Ed.), Environmental Quality in a Growing Economy (pp. 3-14). Baltimore: Johns Hopkins University Press.

Briem, A-K., Betten, T., Held, M., Wehner, D., \& Baumann, M. (2019). Environmental sustainability in the context of mass personalisation - quantification of the carbon footprint with life cycle assessment. International Journal of Industrial Engineering and Management (IJIEM), 10 (2), 171-180.

Costanza, R. (2008). Ecological Economics 1, Encyclopaedia of Ecology, 999-1006. Doi: https://doi.org/10.1016/b978-008045405-4.00619-4

Cui, C., Liu, Y., Xia, B., Jiang, X., \& Skitmore, M. (2020). Overview of public-private partnerships in the waste-to-energy incineration industry in China: Status, opportunities, and challenges. Energy Strategy Reviews, 32, 100584. Doi: https://doi.org/10.1016/j.esr.2020.100584

Dakić, S., \& Mijić, K. (2020). Regression analysis of the impact of internal factors on return on assets: A case of meat processing enterprises in Serbia. Strategic Management, 25 (1), 29-34.

Đureta, V., Mutić, M., Mitrović, S., \& Bogdanović, M. (2016). Osnove cirkularne ekonomije. Beograd: Deutsche Gesellschaft für Internationale Zusammenarbeit (GIZ) $\mathrm{GmbH}$.

European Bank for Reconstruction and Development (2018, March). From waste to resources: mobilising the private sector to deliver sustainable waste management. Retrieved February 23, 2021, from https://www.ebrd.com/documents/climate-finance/fromwaste-to-resources-mobilising-the-private-sector-to-deliver-sustainable-wastemanagement.pdf

Fiscal Council of the Republic of Serbia (2018, Jun 26). Инвестиције y заштиту животне средине: друштвени и фискални приоритет. Retrieved February 25, 2021, from http://www.fiskalnisavet.rs/doc/analize-stavovi-predlozi/FS-Investicije-u-zastituzivotne-sredine.pdf

Flanders Investment and Trade (2017, May). Solid Waste Sector in Serbia - Overview. Retrieved January 24, 2021, from https://www.flandersinvestmentandtrade.com/export/sites/trade/files/market studies/Solid \%20Waste $\% 20$ Serbia $\% 20-\% 20$ Overview $\% 20-\% 20$ DEF.pdf

Grabowski, J., \& Vasconcelos, G. (1993). Reasonable investments in environmental protection can make people richer. Chemosphere, 26(5), 1003-1013. Doi: https://doi.org/10.1016/0045-6535(93)90373-d 
Hora, M., Hankammer, S., Canetta, L., Kaygın Sel, S., Gomez, S., \& Gahrens, S. (2016). Designing Business Models for Sustainable Mass Customization: A Framework Proposal. International Journal of Industrial Engineering and Management (IJIEM), 7 (4), 143-152.

Huang, W., Wang, J., Dai, X., Li, M., \& Harder, M. K. (2014). More than financial investment is needed: food waste recycling pilots in Shanghai, China. Journal of Cleaner Production, 67, 107-116. Doi: https://doi.org/10.1016/j.jclepro.2013.12.019

Kalaš, B. (2015). The importance of foreign direct investment in function of sustainable development. The Annals of the Faculty of Economics in Subotica, 51 (33), 217-235. Doi:

Maia, L. C., Alves, A. C., \& Leão, C. P. (2013). Sustainable work environment with lean production in textile and clothing industry. International Journal of Industrial Engineering and Management (IJIEM), 4 (3), 183-190, ISSN: 2217-2661.

Martinez-Alier, J. (2001). Ecological economics. International Encyclopaedia of the Social \& Behavioural Sciences, 4016-4023. Doi: https://doi.org/10.1016/b0-08-043076-7/04135-8

Mesjasz-Lech, A. (2014). Municipal waste management in context of sustainable urban development, Procedia - Social and Behavioural Sciences, 151, 244 - 256. Doi: https://doi.org/10.1016/j.sbspro.2014.10.023

Neo, H. (2009). Resource and environmental economics. International Encyclopaedia of Human Geography, 376-380. Doi: https://doi.org/10.1016/b978-008044910-4.00225-x

Nešić, B. (2010). Upravljanje komunalnim otpadom $i$ potencijali za reciklažu južne $i$ jugoistočne Srbije. Niš: Center for Civil Society Development.

Nunes, K. R. A., Mahler, C. F., Valle, R., \& Neves, C. (2007). Evaluation of investments in recycling centres for construction and demolition wastes in Brazilian municipalities. Waste Management, 27 (11), 1531-1540. Doi: https://doi.org/10.1016/j.wasman.2006.09.007

Obradović, S., \& Lojanica, N. (2015). Foreign Direct Investment and Income Inequality Evidence from Developing Economies. The Annals of the Faculty of Economics in Subotica, 51 (34), 003-013.

Petrović, E., \& Denčić-Mihajlov, K. (2011). Poslovne finansije. Niš: Univerzitet u Nišu, Ekonomski fakultet.

Serbian Environmental Protection Agency. (2018). Извештај о стағу животне средине у Републии Србији, Retrieved February 14, 2021, from

http://www.sepa.gov.rs/download/Izvestaj2018.pdf

Serbian Environmental Protection Agency. (2020, September). Upravljanje otpadom $u$ Republici Srbiji u periodu 2011-2019. godine. Retrieved January 22, 2021, from

http://www.sepa.gov.rs/download/Otpad_2011-2019_Finale.pdf 
Shen, L., Koveos, P., Zhu, X., Wen, F., \& Liao, J. (2020). Outward FDI and entrepreneurship: the case of China. Sustainability, 12 (13), 5234. Doi: https://doi.org/10.3390/su12135234

Sredojević, Z., Kljajić, N., \& Gajić, B. (2019). Brownfield investments as possibility of revitalization and sustainability of locations. Ekonomika poljoprivrede, 66 (2), 589-599.

Stepanov, J. (2018). Model za evaluaciju sistema upravljanja komunalnim otpadom primenom metode ocenjivanja životnog ciklusa. Unpublished doctoral dissertation, University of Novi Sad, Faculty of Technical Sciences, Novi Sad, Serbia.

Stojanović, D., Ilić, B., \& Moračanin, J. (2017). Sustainable development of local communities in Serbia and FDI. Ekonomika, 63(3), 77-86. Doi: https://doi.org/ $\underline{10.5937 / \text { ekonomika17030775 }}$

Ugrinov, D., \& Stojanov, A. (2010). Bioremedijacija u tretmanu zagađenog zemljišta. Zaštita materijala, 51 (4), 237-244.

University of Yale, Environmental Performance Index. (2020). Retrieved February 25, 2021, from https://epi.yale.edu/epi-results/2020/component/epi

Valović Begović, S., Momčilović, M., \& Tomašević, S. (2017). Economic efficiency assessment of investment. The Annals of the Faculty of Economics in Subotica, 54(39), 187-204. Doi: https://doi.org/10.5937/AnEkSub1839187V

World Bank. (2018). Private Participation in Infrastructure, Municipal Solid Waste $(M S W)$. Retrieved January 24, 2021, from

https://ppi.worldbank.org/content/dam/PPI/documents/MSW\%20Infographic\%20Updated \%201908.pdf

Zhonghua, C., \& Yu., S. (2011). Environmental protection investment and sustainable development-policy simulation based on nonlinear dynamics. Energy Procedia, 5, 467471. Doi: https://doi.org/10.1016/j.egypro.2011.03.081

Živančev, M., Milovanović, D., Bežanović, V., Novaković, M., Petrović, M., \& Ubavin, D. (2020). Contribution of waste management sector in Novi Sad to climate change. Paper presented at the 28th International Conference Ecological Truth \& Environmental Research, Kladovo, Serbia. 